\title{
అ0@
}

Jurnal Terapan Manajemen dan Bisnis is licensed under

A Creative Commons Attribution-Non_Commercial 4.0 International License.

\section{UTILIZING FLANEL FABRIC TO BE A TAKSI (TAS KEREASI SENDIRI) BAG OF YOUR OWN CEATIONS}

\author{
Zulfahita ${ }^{1)}$, Hilda Januarti ${ }^{2),}$ Giri Wulandarii3), Elsi Tamara ${ }^{4)}$, Orlando ${ }^{5)}$ \\ 1234)STKIP Singkawang, Singkawang, Indonesia \\ E-mail: zulfahita@yahoo.co.id,hildajanuarti.06@gmail.com, \\ gwulandari84@gmail.com,elsishera@gmail.com \\ 5)Shandong University of Science and Technology, Qingdao, China \\ E-mail: 1786395532@163.com
}

\begin{abstract}
For the student creativity program in this entrepreneurship class, we run a business program for making our own bags from flannel. The flannel cloth itself is easy to find in the nearest shops and the price is also quite affordable. Besides being easy to get, flannel is also easy to make several forms of crafts, one of which is a bag. The bag that we are going to make is a sling bag model, where this model is loved by children today or it can be called a trend. Here what we need in addition to tools and materials is that we need skills and creative power. So that the bag that we will make can attract consumers to buy. In the community, there are many bags that make consumers want to buy them, but the prices are less affordable for consumers. Therefore, we take advantage of this situation to make bags of our own creations in order to help consumers to support their appearance with the bags that we make, of course, these bags are cheap in the pockets of students and teenagers.
\end{abstract}

Keywords: crafts, flannelette, bag creations, TAKSI

\section{Introduction}

You know flannel? Yes, the colorful fabrics that people usually use to be creative channel the ideas that are in our heads. Even in creative hands, flannel can be transformed into trendy and useful handicraft items. According to Natasande in (K.S Manik, 5: 2013) flannel is the oldest type of cloth in the history of human civilization, older than woven and knitted fabrics. Making flannel crafts, it turns out that it is not as complicated as we imagine, it is quite a bit of our accuracy and creativity. Flannel is also very easy to find in fabric knickknacks and accessories stores. This flannel cloth can be used as handicraft items such as beautiful and unique bags.

This business is engaged in the home craft industry. The home craft industry according to Arsyad in (Hasanah 171: 2011) is an industry that employs less than three people (including unpaid labor). Basically, the home craft industry was established to seek profit and to meet the needs of a consumer's demand for a quality and quality product. Meanwhile, the creation of good quality and quality at a low cost is the main requirement if you want increased profits. The bag business itself 'TAKSI' has several advantages, including: Variety of shapes, characters and various colors, such as black rectangular with raindrops character, animated kawai cat shape, round shape with flower decorations, and others. . And also the 
benefits of this product so that people get goods that can help beautify the appearance of consumers at affordable prices. For ourselves, so that we can help in developing creativity.

\section{Literature Review}

\section{A. Activity benefits}

Our target market is teenagers, students and university students. The target market according to Jaya (6: 2011) is the market segments or groups or customers planned by retailers to be served due to limited resources that retailers have and must prepare at once. We determine our marketing location later through social media and our closest friends because it is more effective. We will market our products on our social accounts. And we will offer it to friends around our environment.

B. Products

Products are goods that have been produced from something that will be offered to consumers. According to Kotler in (Habibah, 35: 2016) a product is anything that can be offered to the market to get attention, buy it for use, or consume it that can satisfy wants or needs. Products that are produced from flannel into bags are of various shapes depending on the tastes and orders of consumers who want to buy the products we have produced, including:

1. Rectangular bag.

2. Floral-patterned bags, and others.

C. Business Location

The location of the business is very important and very supportive for the development or failure of a business in the future. In determining the location of our business, we choose the available social media as well as in residential and campus areas.

\section{Research Methods}

A. Observation

The first thing to do is make direct observations of the environment around us. The purpose of observing the surrounding environment is to look for business opportunities that can develop well in the future. Because people around us prefer to use cellphones or gadgets, therefore we think our products are more effective when sold via social media. Apart from that, we can also market our products around our environment.

B. Making Business Planning

The next step after getting the idea to start a business is to make a business plan. In this business planning, it explains the business background, type of business, business location, marketing strategy for the schedule of activities, sources of funds, estimated costs required, revenue, and the benefits that will be obtained. In addition, it also includes a business feasibility analysis that we will carry out.

C. Marketing strategy

The marketing strategy of our group is carried out to support the success of our business. The marketing strategy according to Craven in (Yuliana, 4: 2013) is an analysis of the development strategy and the implementation of activities in the strategy for determining the market for products in each business unit, setting marketing objectives, developing, implementing, and managing the marketing program strategy, determining the market position that is designed to meet the desires of target market consumers. The marketing strategies that we have created are:

1. Make your own bags with various characters and shapes that are of course liked by all circles, both children and adolescents. 
2. Selling products at prices affordable to the community.

3. Offering products via online and also directly to colleagues or classmates.

D. Tools and Materials

Table 1. tools and materials

\begin{tabular}{cll}
\hline No. & & \multicolumn{1}{c}{ Materials } \\
\hline 1. & Needle & flannelette \\
2. & Scissor & Zippers \\
3. & Pencil & Buttons \\
4. & Ruler & Artificial eyes \\
5. & Large Kater & Yarn \\
6. & Glue gun & Glue wax \\
7. & Big meter & Rope kur \\
8. & Eraser & Bag Clamp \\
\hline
\end{tabular}

\section{Results and Discussion}

A. Business Preparation

The business preparation referred to here is to prepare all the equipment needed to start this creative bag business, including how to design the promotional media that will be used.

B. Starting a business

Making your own bag of flannel can be done well through careful preparation. The cooperation to start the preparation of this "TAKSI" business must be well established, besides that we also prepare all the materials and necessities needed for the manufacture of this bag. We will prepare a place or business location that we will use for the process of making this bag of our own creations so that we no longer need to move around equipment and tools for making bags because we already have our own business premises.

C. How to load a bag from flannel, namely:

1. Prepare the materials and tools needed.

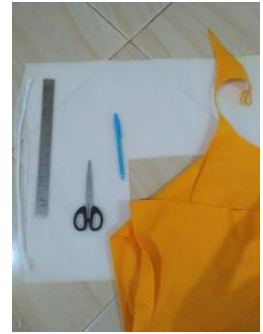

Picture 1. Tools and materials

2. The next step in how to make this handbag, we can make a pattern first at the top using a blank paper.

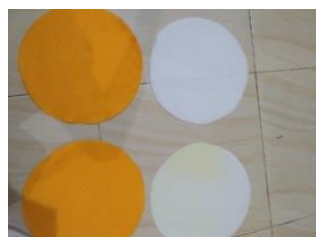

Picture 2. Make a pattern

3. Then, apply the pattern to the flannel cloth and cut the flannel with the same size and stitch them together. 


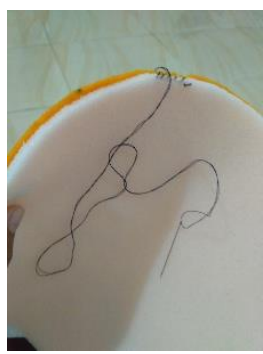

Picture 3. Sew the pattern with flannelette

4. Attach the bag strap and in order to add an attractive impression, attach a zipper and some decorative bag accessories according to the character we want.

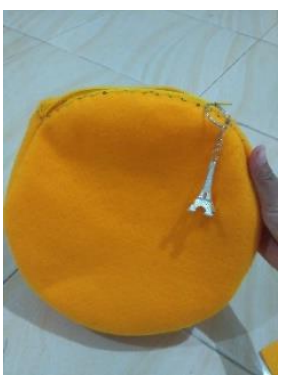

Picture 4. Attach the Strap and Accessories on the bag

5. Now, the flannel character bag is ready and ready to use.

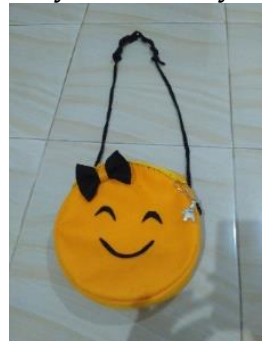

D. Place of business

Picture 5. Ready made character bag.

The products that we market, through social media and offer them in our environment.

\section{Conclusion}

For the student creativity program in this entrepreneurship class, we run a business program for making our own bags from flannel. The flannel cloth itself is easy to find in the nearest shops and the price is also quite affordable. Besides being easy to get, flannel is also easy to make several forms of crafts, one of which is a bag. The bag that we are going to make is a sling bag model, where this model is loved by children today or it can be called a trend. Here what we need in addition to tools and materials is that we need skills and strong creative power. So that the bag that we will make can attract consumers to buy. The form of our business is still in an individual stage and this business is still new and still trying to enter the world of business. But we already have our own business brand, namely "TAKSI" which means your own creation bag.

\section{References}

Hasanah, E. U., \& Widowati, P. (2011). Analisis Produktivitas Tenaga Kerja pada Industry Rumah Tangga Krecek di Kelurahan Segoroyoso. Efektif Jurnal Bisnis dan Ekonomi, 2(2), 169-182. 
Jaya, P. I. N. T. O., Fadillah, A. D. I. L., \& Bawono, S. (2012). Anlisis Strategi Usaha Ritel UKM Dalam Meningkatkan Keunggulan Bersaing Studi Kasus Pada UKM Toko Mojang Fashion. In 2012 Marketing Symposium, 1 (1).

Manik, K, S., Jampel, N., \& Parmiti, D, P. (2013). Penerapan Metode Sosiodrama Berbantuan Media Kain Flanel Untuk Meningkatkan Kemampuan Bahasa Anak Kelompok B di TK Dharma Bhakti. Jurnal Pendidikan Anak Usia Dini Undiksha, 1(1).

Munadi, F, A., Ekonomi, F., \& Gunadarma, U. (2008). Analisis Strategi Pemasaran untuk Meningkatkan Penjualan Kendaraan Motor pada CV Turangga Mas Motor. Journal of Econpmic, 1-14.

Saputra, S. T., Hidayat, K., \& Sunarti, S. (2017). Pengaruh Kualitas Produk Terhadap Keputusan Pembelian dan Dampaknya Terhadap Kepuasan Konsumen Pengguna Iphone (Survei pada Mahasiswa Fakultas Ilmu Administrasi Universitas Brawijaya Malang). Jurnal Administrasi Bisnis, 50(6), 85-95 